\title{
Photoacclimation in three species of freshwater red algae
}

\author{
Anna I.N. Bautista and Orlando Necchi Jr.*
}

Zoology and Botany Department, São Paulo State University, Rua Cristóvão Colombo, 2265 15054-000 São José do Rio Preto, SP, Brazil.Phone (17) 3221-2406; fax (17) 3221-2374*Corresponding author: orlando@ibilce.unesp.br

Received: 27 February 2007; Returned for revision: 11 April 2007; Accepted: 30 April 2007

Three freshwater Rhodophyta species (Audouinella eugenea, A. hermannii and Compsopogon coeruleus) were tested as to their responses (photosynthesis, growth and pigment concentration) to two irradiances (low light, LL, $65 \mu \mathrm{mol} \mathrm{m} \mathrm{m}^{-2} \mathrm{~s}^{-1} \mathrm{and} \mathrm{high}$ light, HL, $300 \mu \mathrm{mol} \mathrm{m}^{-2} \mathrm{~s}^{-1}$ ) and two periods (short time, ST, $4 \mathrm{~d}$, and long time, LT, $28 \mathrm{~d}$ ). Higher growth rates were consistently observed at LL but significant differences were observed only for A. hermannii. Higher values of photoinhibition at LL were found for the three species, which is consistent with the dynamic photoinhibition as a reversible photoprotective mechanism against high irradiance. Light-induced decreases of effective quantum yield (EQY) were observed in the three species consisting of pronounced decreases from LL to HL. Rapid increases of non-photochemical quenching (NPQ) were observed mainly at LL, indicating energy dissipation by reaction centers. Results revealed distinct photoacclimation strategies to deal with high irradiances: the two Audouinella species had only characteristics of shade-adapted algae: acclimation by changes of size of photosystem units (PSU) under LT and by PSU number under ST; higher values of the photoinhibition parameter ( $\beta$ ) and NPQ, and lower values of EQY at LL; higher recovery capacity of potential quantum yield (PQY) at LL and under ST; highly significant positive correlation of electron transport rate (ETR) with NPQ. In addition, C. coeruleus mixed some characteristics of sun-adapted algae: acclimation by changes of PSU number under LT and by PSU size under ST; higher recovery capacity of EQY than the other two species; weak or no correlation of ETR with NPQ. Thus, these characteristics indicate that $C$. coeruleus cope with high irradiances more efficiently than the Audouinella species.

Key words: chlorophyll fluorescence, growth, irradiance, photosynthesis, pigment, red algae

Fotoaclimatação em três espécies de algas vermelhas continentais. Três espécies de Rhodophyta continentais (Audouinella eugenea, A. hermannii e Compsopogon coeruleus) foram testadas em resposta à fotossíntese, crescimento e concentração de pigmento em dois níveis de irradiância (baixa irradiância, BI, $65 \mu \mathrm{mol} \mathrm{m} \mathrm{m}^{-2} \mathrm{~s}^{-1}$ e alta irradiância, AI, $300 \mu \mathrm{mol} \mathrm{m} \mathrm{m}^{-2} \mathrm{~s}^{-1}$ ) e dois períodos (curto período, CP, 4 d e longo período, LP, 28 d). Observaram-se maiores taxas de crescimento em BI, mas diferenças significativas foram encontradas apenas em A. hermannii. Observaram-se maiores valores de fotoinibição em BI para as três espécies, consistentes com a dinâmica de fotoinbição como um mecanismo fotoprotetor reversível contra alta irradiância. Nas três espécies, verificou-se diminuição induzida por luz no rendimento quântico efetivo, consistindo de forte queda de BI para AI. Aumentos rápidos de extinção não-fotoquímica (NPQ) foram observados principalmente em BI, indicando dissipação do excesso de energia pelos centros de reação. Os resultados revelaram estratégias distintas de fotoaclimatação para enfrentar altas irradiâncias: espécies de Audouinella exibiram somente características de algas adaptadas à sombra: aclimatação por mudanças do tamanho das unidades dos fotossistemas (UF) sob LP e por número de UF sob CP; valores maiores do parâmetro de fotoinibição e NPQ e menores de rendimento quântico efetivo (RQE) em BI; maior capacidade de recuperação de rendimento quântico potencial (RQP) em BI e sob CP; correlação positiva altamente significante entre taxa relativa de transporte de elétrons (TTE) com NPQ. Compsopogon coeruleus apresentou características de algas adaptadas ao sol: aclimatação por mudanças no número de UF sob LP e de tamanho de UF sob CP; maior capacidade de recuperação de RQE; correlação baixa ou nenhuma correlação entre TTE e NPQ. Assim, estas características indicam que C. coeruleus enfrenta altas irradiâncias mais eficientemente do que as espécies de Audouinella.

Palavras-chave: crescimento, fotossíntese, fluorescência, irradiância, pigmento, alga vermelha

\footnotetext{
Abbreviations: EQY - effective quantum yield of photosystem II; ETR - electron transport rate; I - compensation irradiance; I $\mathrm{I}_{\mathrm{k}}$ saturation parameter; NPQ - non-photochemical quenching coefficient; PAR - photosynthetic active radiation; PI - photosynthesisirradiance; $\mathrm{P}_{\max }$ - maximum photosynthetic rate; PQY - potential quantum yield of photosystem II; PSU - photosystem units; RGR relative growth rate; $\alpha$ - photosynthetic efficiency; $\beta$ - photoinhibition parameter
} 


\section{INTRODUCTION}

Light is one of the major environmental factors controlling growth, pigment content and photosynthetic rate in freshwater red algae (Sheath, 1984; Necchi, 2005). Physiological acclimation to changes in light intensity and spectral quality is an important factor determining variations in photosynthetic responses and growth rates of algae (Falkowski and LaRoche, 1991). Light variations at distinct time-scales affect algal photosynthesis in many different ways, with diurnal, seasonal or annual responses (Kirk, 1994). Photoacclimation occurs in response to irradiance and spectral distribution, but much more information is available about changes in responses to irradiance (Falkowski and LaRoche, 1991). Red algae have evolved a number of long- and short-term strategies to survive under changing light fields, involving changes from individual to molecular levels (Talarico and Maranzana, 2000).

Algae usually follow one of two basic photoacclimation strategies (Ramus, 1981; Falkowski and La Roche, 1991): one consists of an alteration in the size of photosynthetic units (PSU) and the other of a change in the number of PSU. Photosynthetic units are generally defined as the reaction center and its associated lightharvesting pigment complex (Ramus, 1981). Both strategies can be found within algal groups (Perry et al., 1981; Falkowski et al., 1985) and even within a same species (Gallagher et al., 1984). In addition, photoacclimation can occur by an adjustment of both number and size of PSUs in some species (Ramus, 1981).

Investigations have shown an increasing interest in photoacclimation in red algae. Kaczmarczyk and Sheath (1991) studied the effect of light regime (irradiance and spectral composition) and photoacclimation in Batrachospermum boryanum under laboratory conditions and concluded that the alga was equally productive under most of the visible spectrum. They have also shown that total irradiance controlled most pigment alterations, whereas ratios of phycocyanin to phycoerythrin tended to decrease as irradiance increased. Ritz et al. (2000) analyzed the major changes occurring during photoacclimation of Rhodella violacea to a light stress (transferred from low to high irradiance). They showed that the ability of the alga to photoacclimate depends both on large changes in thylakoid number and pigment content and on smaller changes in the antenna size of photosystem II (PSII). Sagert and Schubert (2000) examined the acclimation of the photosynthetic apparatus of Palmaria palmata to irradiance under field and laboratory conditions. They found that the saturation parameter $\left(\mathrm{I}_{\mathrm{k}}\right)$ was affected mainly by light dose, whereas pigment content was dependent on the amplitude of variations in incident irradiance.

Freshwater red algal responses to irradiance have been investigated in relation to growth and pigment content (Zucchi and Necchi, 2001) and photosynthetic characteristics (Necchi and Zucchi, 2001; Necchi, 2005). Parameters derived from photosynthesis-irradiance curves indicated that they are typically shade-adapted plants, indicated by occurrence of photoinhibition, low values of $I_{k}$ and compensation irradiance $\left(I_{c}\right)$, and high values of the effective quantum yield of photosystem II (EQY). On the other hand, some species can tolerate high irradiances (up to $2,400 \mu \mathrm{mol} \mathrm{m}{ }^{-2} \mathrm{~s}^{-1}$ ), suggesting they have mechanisms that enable them to avoid photodamage of the photosynthetic apparatus. Photoacclimation was evidenced in some populations, as revealed by lower values of $I_{k}$ and $I_{c}$ and higher values of EQY in algae under low irradiances (shaded or heavily shaded stream segments), and vice-versa. Despite the progress from the previous investigations, acclimation and recovery capacity of photosynthesis, changes of growth and pigment content in response to varying irradiances and exposure times are still little documented.

It should be remembered that freshwater red algae are considered to be shade-adapted algae in addition to being often exposed (daily and seasonally) to relatively high irradiances at their natural habitats. Therefore they might have mechanisms to cope with such irradiances, but such mechanisms, particularly those related to light acclimation to distinct irrandiance levels, are poorly described. This study was initiated aiming at describing the acclimation characteristics of three freshwater red algal species under contrasting irradiance levels and exposure periods.

\section{MATERIAL AND METHODS}

Three freshwater red algal species from unialgal culture isolates were tested: Audouinella eugenea (Skuja) Jao (isolate no. 107), A. hermannii (Roth) Duby 
(isolate no. 38) and Compsopogon coeruleus (C. Agardh) Montagne (isolate no. 58). These species were chosen aiming to evaluate species-specific responses (two species of the genus Audouinella), as well as those referring to higher taxonomic levels (genus-specific responses) and morphological types: tuft (Audouinella) and non-mucilaginous filament (Compsopogon).

These algae were kept in a 20:1 water-soil culture medium (Zucchi and Necchi, 2001) with an initial pH of 6.9-7.0 under the following conditions: temperature of 20 $\pm 1^{\circ} \mathrm{C}$, irradiance of $45 \pm 5 \mu \mathrm{mol} \mathrm{m} \mathrm{m}^{-2} \mathrm{~s}^{-1}$ and photoperiod of $12 \mathrm{~h}$. Experiments were initiated from cultures in exponential growth. Incubations were conducted in RI 12-555 Revco incubators with illumination from above supplied by two to four cool-white fluorescent lamps (Osram $15 \mathrm{~W}$ ). Irradiances within the incubators were adjusted by moving the shelves or using a neutral black mesh. Photoacclimation experiments followed a 2 × 2 factorial design, consisting of: two irradiances, low and high, $65 \pm 5$ and $300 \pm 10 \mu \mathrm{mol} \mathrm{m}^{-2} \mathrm{~s}^{-1}$, respectively; and two time periods, short $-4 \mathrm{~d}-$ and long $-28 \mathrm{~d}$. All treatments were conducted at $20^{\circ} \mathrm{C}$. These irradiance levels were used in a previous study (Zucchi and Necchi, 2001) and shown to produce reliable responses. The duration of experiments was determined from preliminary experiments and on the basis of the statement by Falkowski and Raven (1997) that photoacclimation in algae ranges from 26 to $100 \mathrm{~h}$.

Growth was based on initial and final fresh weights (Zucchi and Necchi, 2001). Plant segments were grown from initial fresh weights of $2.0 \pm 0.5 \mathrm{mg}$, and the relative growth rate (RGR) was calculated by the formula (Kain, 1987): $\operatorname{RGR}\left(\% \mathrm{~d}^{-1}\right)=100\left(\ln \mathrm{W}_{\mathrm{t}}-\ln \mathrm{W}_{0}\right) \mathrm{t}^{-1}$, where $\mathrm{W}_{0}=$ initial fresh weight, $\mathrm{W}_{\mathrm{t}}=$ final fresh weight, $\mathrm{t}=$ time (days). Thalli were blotted dry and then weighed (resolution 0.1 $\mathrm{mg})$. Five replicates were used in experiments, each consisting of a culture tube $(25 \times 120 \mathrm{~mm})$ with $30 \mathrm{~mL}$ of culture medium. The position of tubes within each set was changed at 5-d intervals to minimize irradiance differences among the replicates.

At the end of the growth period (after determining $\mathrm{W}_{\mathrm{t}}$ ), the algal material from the replicates was used for pigment determination. Plants were frozen for 15 to $30 \mathrm{~d}$ before pigment extraction. Phycobiliproteins (phycocyanin and phycoerythrin) were extracted in $0.1 \mathrm{M}$ phosphate buffer ( $\mathrm{pH}$ 6.8) and quantified according to the spectrophotometric technique of Beer and Eshel (1985), with a B 342-II spectrophotometer (Micronal, São Paulo, Brazil). Chlorophyll $a$ was extracted by resuspending the pellet resulting from phycobiliprotein extraction in $90 \%$ alkaline acetone, and determined by a spectrophotometric technique (Wetzel and Likens, 2000). Pigment extraction and absorbance readings were conducted under dim light to avoid degradation.

Photosynthesis was measured by in vivo chlorophyll fluorescence using a Diving-PAM underwater fluorometer (Walz, Effeltrich, Germany). Entire algal thalli were placed directly on the tip of the fluorometer fiberoptic using the supplied magnet sample holder. Photosynthesis-irradiance (PI) curves, as rapid light curves (White and Critchley, 1999), consisted of the fluorescence responses to eight increasing irradiances from 0 to $690 \mu \mathrm{mol} \mathrm{m}{ }^{-2} \mathrm{~s}^{-1}$, using the "light curve" option of the Diving-PAM. The exposure time at each irradiance was $15 \mathrm{~s}$, each separated by a saturating flash $(0.8 \mathrm{~s}$, $\left.\sim 6,000 \mu \mathrm{mol} \mathrm{m}{ }^{-2} \mathrm{~s}^{-1}\right)$. Four parameters were determined from each sample: 1$)$ potential quantum yield (PQY) of PSII $\left(F_{\mathrm{v}} / F_{\mathrm{m}}\right)$, where $F_{\mathrm{v}}=$ variable fluorescence and $F_{\mathrm{m}}=$ maximal fluorescence of dark-acclimated samples [for dark acclimation, apices of algal thalli were placed for 5 min (Necchi, 2005) directly on the tip of the fiberoptic using the supplied dark leaf clip]; 2) EQY $\left(\Delta F / F_{\mathrm{m}}{ }^{\prime}\right)$, where $F=F_{\mathrm{m}}{ }^{\prime}-F_{\mathrm{t}}, F_{\mathrm{m}}{ }^{\prime}=$ maximal fluorescence of an illuminated sample, and $F_{\mathrm{t}}=$ transient fluorescence (Schreiber et al., 1994); 3) electron transport rate (ETR). The absorption coefficient (amount of absorbed irradiance by PSII in an optical cross section) was estimated by each alga tested, based on measurements made with and without the alga within a circle of $0.5 \mathrm{~cm}$ in diameter (similar to the area of the fluorometer fiberoptic tip). ETR was calculated as EQY x PAR $x$ absorption coefficient $x$ 0.5, where PAR is the actinic irradiance in $\mu \mathrm{mol} \mathrm{m} \mathrm{m}^{-2} \mathrm{~s}^{-1}$; 4) nonphotochemical quenching (NPQ), a measure of heat dissipation of absorbed light energy, calculated as: NPQ $=\left(F_{\mathrm{m}}-F_{\mathrm{m}}{ }^{\prime}\right) / F_{\mathrm{m}}{ }^{\prime}, F_{\mathrm{m}}$ and $F_{\mathrm{m}}{ }^{\prime}$ (as explained above); NPQ was taken at the highest PAR of the light curve $(690 \mu \mathrm{mol}$ $\left.\mathrm{m}^{-2} \mathrm{~s}^{-1}\right)$. The calculations and terminology followed Schreiber et al. (1994) and van Kooten and Snel (1990), respectively. Curves of PI were generated on the basis of ETR and the respective parameters were calculated applying the equation of Platt et al. (1980): photosynthetic efficiency ( $\alpha$ ETR), "light saturated" $\mathrm{P}_{\max }$ 
$\left(\mathrm{ETR}_{\max }\right)$, saturation parameter $\left(\mathrm{I}_{\mathrm{k}}\right)$ and photoinhibition parameter ( $\beta$ ETR). The values of $\alpha$ ETR were determined by linear fitting using the first three points of the ETR versus irradiance curve (Conde-Álvarez et al., 2002).

Dark/light induction (Kautsky) curves were performed on thalli dark-acclimated for 5 min with application of a constant actinic irradiance $\left(170 \mu \mathrm{mol} \mathrm{m}^{-2}\right.$ $\mathrm{s}^{-1}$ ) using the halogen light source of the Diving-PAM, separated by eight saturating light pulses at $15 \mathrm{~s}$ intervals, initiated $30 \mathrm{~s}$ after the first saturation pulse.

First, a saturation pulse was applied for determination of PQY $\left(F_{\mathrm{v}} / F_{\mathrm{m}}\right)$ (Schreiber et al, 1994). For dark acclimation, apices or entire algal thalli were placed directly on the tip of the fiberoptic using the supplied dark leaf clip. Measurement of NPQ was made as explained above.

Parametric statistical tests were applied considering that the variables followed a normal distribution according to graphical assessment of normality based on the regression curves. Student's $t$ test (Zar, 1999) was used to evaluate significant differences $(P<0.05)$ in photosynthetic parameters, growth and pigment contents between low and high irradiances within each period (short and long). Relationships of these three physiological variables in each treatment (low vs. high irradiance and short $v s$. long-term) were evaluated with the Pearson moment-product correlation coefficient (Zar, 1999). Statistical tests were performed using Statsoft Statistica 6.0 software, whereas graphs and calculations from PI curve parameters were made using Microcal Origin 5.0.

\section{RESULTS}

Photoacclimation of growth, PI curves and pigment content: Higher RGR was consistently observed at low irradiance but significant differences were found only for A. hermannii (Table 1).

Photosynthetic parameters in short-term had significantly higher values of $\mathrm{P}_{\text {max }}$, alpha, beta, EQY and NPQ at low irradiance for A. eugenea and A. hermannii, whereas significantly higher values of $I_{k}$ were observed at high irradiance (Table 2, Figure 1). Values of $\beta$ and $I_{k}$ were higher but not significantly different at low irradiance for A. engenea. The pattern observed for $C$. coeruleus was essentially similar, except for significantly higher values of $\mathrm{P}_{\max }$ observed at high irradiance (Table 2, Figure 1).
Table 1. Relative growth rate $\left(\% \mathrm{day}^{-1}\right)$ for the three freshwater red algal species under low $\left(65 \mu \mathrm{mol} \mathrm{m}^{-2} \mathrm{~s}^{-1}\right)$ and high $\left(300 \mu \mathrm{mol} \mathrm{m}^{-2} \mathrm{~s}^{-1}\right)$ irradiances in long-term light acclimation. Data are expressed as means $\pm \mathrm{SD}(n=5)$. Distinct letters indicate significant differences $(P<0.01)$ by Student's $t$ test.

\begin{tabular}{lc}
\hline Species/treatment & Relative growth rate \\
\hline Audouinella eugenea & \\
$\quad$ Low irradiance & $2.90 \pm 0.99 \mathrm{a}$ \\
High irradiance & $2.34 \pm 1.16 \mathrm{a}$ \\
Audouinella hermannii & \\
$\quad$ Low irradiance & $3.65 \pm 0.62 \mathrm{a}$ \\
$\quad$ High irradiance & $0.70 \pm 1.14 \mathrm{~b}$ \\
Compsopogon coeruleus & \\
$\quad$ Low irradiance & $1.64 \pm 0.97 \mathrm{a}$ \\
High irradiance & $1.32 \pm 0.86 \mathrm{a}$ \\
\hline
\end{tabular}

Photosynthetic parameters in long-term had essentially the same pattern with significantly higher values of $\alpha, \beta$, EQY and NPQ at low irradiance for A. eugenea and A. hermannii, whereas significantly higher values of $\mathrm{I}_{\mathrm{k}}$ were observed at high irradiance (Table 2, Figure 1). However, values of $\mathrm{P}_{\max }$ were not significantly different between low and high irradiance for these two species. The trend observed for $C$. coeruleus was mostly similar, except for $\mathrm{P}_{\max }$ values significantly higher at low irradiance and no significant difference found for values of $\beta$ between low and high irradiances (Table 2, Figure 1).

The only significant differences in pigment content between low and high irradiance were found for chlorophyll $a$ : higher values at low irradiance for $A$. eugenea and A. hermannii and at high irradiance for $C$. coeruleus in long-term, whereas higher values at low irradiance in short-term were only found for A. eugenea (Table 3). In addition, higher ratios of phycobiliprotein to chlorophyll $a$ were observed for A. eugenea, but only in the short-term.

Photoacclimation of dark/light induction curves: Dark/ light induction curves for ETR showed an increase for 1 min to $1: 30 \mathrm{~min}$ and then a slight decrease at low irradiance in short-term for the three species (Figure 2). An increasing initial trend was also observed at high irradiance, but it lasted longer (1:15 to $1: 45)$ and with a slight decrease thereafter (Figure 2). Values of ETR were significantly higher at low irradiance $(t=3.4-17.2, P<$ 0.01 ), except for A. eugenea in short-term and for $A$. 
Table 2. Parameters $\left(\mathrm{P}_{\max }\right.$, maximum photosynthetic rate; $\alpha$, photosynthetic efficiency; $\beta$, photoinhibition parameter; $\mathrm{I}_{\mathrm{k}}$, saturation parameter; EQY, effective quantum yield; and NPQ, nonphotochemical quenching coefficient) derived from the photosynthesisirradiance curves for the three freshwater red algal species tested under low $\left(65 \mu \mathrm{mol} \mathrm{m}^{-2} \mathrm{~s}^{-1}\right)$ and high $\left(300 \mu \mathrm{mol} \mathrm{m} \mathrm{m}^{-2}\right)$ irradiances in short- $(4 \mathrm{~d})$ and long-term $(28 \mathrm{~d})$ light acclimation. Data are expressed as means $\pm \mathrm{SD}(n=5)$. Distinct letters indicate significant differences $(P<0.05)$ by Student's $t$ test.

\begin{tabular}{|c|c|c|c|c|c|c|}
\hline \multirow{2}{*}{ Species/treatment } & \multicolumn{2}{|c|}{ Audouinella eugenea } & \multicolumn{2}{|c|}{ Audouinella hermannii } & \multicolumn{2}{|c|}{ Compsopogon coeruleus } \\
\hline & Low light & High light & Low light & High light & Low light & High light \\
\hline \multicolumn{7}{|l|}{ Parameter } \\
\hline \multicolumn{7}{|l|}{ Short-term } \\
\hline $\mathrm{P}_{\max }(\mathrm{ETR})$ & $22.2 \pm 1.7 \mathrm{a}$ & $10.3 \pm 0.9 b$ & $22.3 \pm 0.5 \mathrm{a}$ & $10.8 \pm 0.3 b$ & $15.6 \pm 0.8 \mathrm{a}$ & $18.6 \pm 0.7 \mathrm{~b}$ \\
\hline$\alpha(\mathrm{ETR})$ & $0.14 \pm 0.01 \mathrm{a}$ & $0.07 \pm 0.00 \mathrm{~b}$ & $0.16 \pm 0.01 \mathrm{a}$ & $0.05 \pm 0.01 \mathrm{~b}$ & $0.17 \pm 0.01 \mathrm{a}$ & $0.12 \pm 0.01 b$ \\
\hline$\beta(\mathrm{ETR})$ & $-0.17 \pm 0.07 \mathrm{a}$ & $-0.01 \pm 0.09 \mathrm{a}$ & $-0.14 \pm 0.02 \mathrm{a}$ & $-0.22 \pm 0.03 b$ & $-0.05 \pm 0.06 \mathrm{a}$ & $-0.17 \pm 0.04 b$ \\
\hline $\mathrm{I}_{\mathrm{k}}\left(\mu \mathrm{mol} \mathrm{m} \mathrm{m}^{-2} \mathrm{~s}^{-1}\right)$ & $79.3 \pm 4.8 \mathrm{a}$ & $73.9 \pm 2.9 \mathrm{a}$ & $71.8 \pm 6.3 \mathrm{a}$ & $112.4 \pm 12.8 b$ & $45.8 \pm 2.0 \mathrm{a}$ & $79.0 \pm 6.0 \mathrm{~b}$ \\
\hline EQY & $0.56 \pm 0.01 \mathrm{a}$ & $0.27 \pm 0.02 b$ & $0.56 \pm 0.08 \mathrm{a}$ & $0.17 \pm 0.05 \mathrm{~b}$ & $0.57 \pm 0.01 \mathrm{a}$ & $0.39 \pm 0.03 b$ \\
\hline NPQ & $0.94 \pm 0.05 \mathrm{a}$ & $0.44 \pm 0.05 b$ & $0.80 \pm 0.23 \mathrm{a}$ & $0.26 \pm 0.05 b$ & $0.85 \pm 0.05 \mathrm{a}$ & $0.74 \pm 0.07 \mathrm{~b}$ \\
\hline \multicolumn{7}{|l|}{ Long-term } \\
\hline $\mathrm{P}_{\max }(\mathrm{ETR})$ & $27.1 \pm 0.5 \mathrm{a}$ & $27.9 \pm 4.4 \mathrm{a}$ & $22.6 \pm 3.0 \mathrm{a}$ & $20.8 \pm 2.00 \mathrm{a}$ & $21.4 \pm 1.2 \mathrm{a}$ & $12.8 \pm 1.6 \mathrm{~b}$ \\
\hline$\alpha(\mathrm{ETR})$ & $0.15 \pm 0.01 \mathrm{a}$ & $0.10 \pm 0.01 \mathrm{~b}$ & $0.15 \pm 0.02 \mathrm{a}$ & $0.10 \pm 0.02 b$ & $0.20 \pm 0.01 \mathrm{a}$ & $0.08 \pm 0.02 \mathrm{~b}$ \\
\hline$\beta(\mathrm{ETR})$ & $-0.13 \pm 0.02 \mathrm{a}$ & $-0.05 \pm 0.02 b$ & $-0.09 \pm 0.03 a$ & $-0.05 \pm 0.01 b$ & $-0.09 \pm 0.06 \mathrm{a}$ & $-0.18 \pm 0.19 a$ \\
\hline 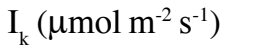 & $92.0 \pm 7.9 \mathrm{a}$ & $137.0 \pm 12.7 \mathrm{~b}$ & $73.5 \pm 3.3 \mathrm{a}$ & $108.6 \pm 13.3 b$ & $53.8 \pm 3.5 \mathrm{a}$ & $78.7 \pm 11.6 b$ \\
\hline EQY & $0.52 \pm 0.04 \mathrm{a}$ & $0.39 \pm 0.07 b$ & $0.54 \pm 0.02 \mathrm{a}$ & $0.35 \pm 0.03 b$ & $0.63 \pm 0.03 \mathrm{a}$ & $0.25 \pm 0.07 b$ \\
\hline NPQ & $0.93 \pm 0.07 \mathrm{a}$ & $0.40 \pm 0.07 b$ & $0.71 \pm 0.13 \mathrm{a}$ & $0.44 \pm 0.07 b$ & $0.99 \pm 0.07 \mathrm{a}$ & $0.44 \pm 0.08 b$ \\
\hline
\end{tabular}

Table 3. Pigment concentrations $\left(\mu \mathrm{g} \mathrm{mg}^{-1} \mathrm{FW}\right)$ for the three freshwater red algal species under low $\left(65 \mu \mathrm{mol} \mathrm{m} \mathrm{m}^{-2} \mathrm{~s}^{-1}\right)$ and high $\left(300 \mu \mathrm{mol} \mathrm{m} \mathrm{s}^{-1}\right)$ irradiances in short- and long-term light acclimation. Data are expressed as means $\pm \operatorname{SD}(n=5)$. Distinct letters indicate significant differences $(P<0.05)$ by Student's $t$ test.

\begin{tabular}{|c|c|c|c|c|c|c|}
\hline \multirow{2}{*}{ Species/treatment } & \multicolumn{2}{|c|}{ Audouinella eugenea } & \multicolumn{2}{|c|}{ Audouinella hermannii } & \multicolumn{2}{|c|}{ Compsopogon coeruleus } \\
\hline & Low & High & Low & High & Low & High \\
\hline \multicolumn{7}{|l|}{ Parameter } \\
\hline \multicolumn{7}{|l|}{ Short-term } \\
\hline Total pigment & $4.42 \pm 0.77 \mathrm{a}$ & $5.10 \pm 1.04 \mathrm{a}$ & $1.69 \pm 1.09 \mathrm{a}$ & $2.21 \pm 0.65 \mathrm{a}$ & $2.39 \pm 1.15 \mathrm{a}$ & $2.85 \pm 1.28 \mathrm{a}$ \\
\hline Phycocyanin (PC) & $1.93 \pm 0.41 \mathrm{a}$ & $2.42 \pm 0.76 \mathrm{a}$ & $0.69 \pm 0.67 \mathrm{a}$ & $1.15 \pm 0.47 \mathrm{a}$ & $1.22 \pm 1.11 \mathrm{a}$ & $1.11 \pm 0.87 \mathrm{a}$ \\
\hline Phycoerythrin (PE) & $2.23 \pm 0.60 \mathrm{a}$ & $2.53 \pm 0.39 \mathrm{a}$ & $0.87 \pm 0.42 \mathrm{a}$ & $0.93 \pm 0.22 \mathrm{a}$ & $0.96 \pm 1.02 \mathrm{a}$ & $1.63 \pm 1.32 \mathrm{a}$ \\
\hline Chlorophyll a (CL) & $0.26 \pm 0.03 \mathrm{a}$ & $0.15 \pm 0.04 b$ & $0.13 \pm 0.02 \mathrm{a}$ & $0.12 \pm 0.04 \mathrm{a}$ & $0.21 \pm 0.09 \mathrm{a}$ & $0.11 \pm 0.18 \mathrm{a}$ \\
\hline Phycobiliproteins/CL & $15.9 \pm 1.04 \mathrm{a}$ & $33.5 \pm 4.7 \mathrm{~b}$ & $12.0 \pm 8.6 \mathrm{a}$ & $18.5 \pm 9.3 \mathrm{a}$ & $16.3 \pm 13.2 \mathrm{a}$ & $33.3 \pm 15.7 \mathrm{a}$ \\
\hline $\mathrm{PC} / \mathrm{PE}$ & $0.9 \pm 0.4 \mathrm{a}$ & $1.0 \pm 0.3 \mathrm{a}$ & $0.7 \pm 0.4 \mathrm{a}$ & $1.2 \pm 0.2 \mathrm{a}$ & $2.2 \pm 2.8 \mathrm{a}$ & $0.6 \pm 0.2 \mathrm{a}$ \\
\hline \multicolumn{7}{|l|}{ Long-term } \\
\hline Total pigment & $1.68 \pm 0.41 \mathrm{a}$ & $1.32 \pm 1.10 \mathrm{a}$ & $1.06 \pm 0.25 \mathrm{a}$ & $0.79 \pm 1.17 \mathrm{a}$ & $1.18 \pm 0.19 \mathrm{a}$ & $1.19 \pm 0.59 \mathrm{a}$ \\
\hline Phycocyanin (PC) & $0.78 \pm 0.34 \mathrm{a}$ & $0.77 \pm 0.77 \mathrm{a}$ & $0.37 \pm 0.09 \mathrm{a}$ & $0.25 \pm 0.56 \mathrm{a}$ & $0.49 \pm 0.27 \mathrm{a}$ & $0.68 \pm 0.42 \mathrm{a}$ \\
\hline Phycoerythrin (PE) & $0.77 \pm 0.14 \mathrm{a}$ & $0.52 \pm 0.35 \mathrm{a}$ & $0.47 \pm 0.16 \mathrm{a}$ & $0.44 \pm 0.64 \mathrm{a}$ & $0.62 \pm 0.24 \mathrm{a}$ & $0.37 \pm 0.22 \mathrm{a}$ \\
\hline Chlorophyll a (CL) & $0.13 \pm 0.06 \mathrm{a}$ & $0.04 \pm 0.03 b$ & $0.22 \pm 0.07 \mathrm{a}$ & $0.11 \pm 0.03 b$ & $0.07 \pm 0.04 \mathrm{a}$ & $0.14 \pm 0.03 b$ \\
\hline Phycobiliproteins/CL & $18.1 \pm 16.8 \mathrm{a}$ & $36.9 \pm 22.9 \mathrm{a}$ & $4.2 \pm 1.6 \mathrm{a}$ & $6.0 \pm 4.2 \mathrm{~b}$ & $23.0 \pm 14.4 \mathrm{a}$ & $8.7 \pm 5.0 \mathrm{a}$ \\
\hline $\mathrm{PC} / \mathrm{PE}$ & $1.0 \pm 0.5 \mathrm{a}$ & $1.4 \pm 0.7 \mathrm{a}$ & $0.8 \pm 0.2 \mathrm{a}$ & $0.2 \pm 0.4 b$ & $1.3 \pm 0.5 \mathrm{a}$ & $2.0 \pm 0.9 \mathrm{a}$ \\
\hline
\end{tabular}

hermannii in long-term (Figure 2). Values of ETR were positively correlated along the curve between low and high irradiance $(r=0.79-0.99, P<0.01)$ in short- and longterm for the three species.
Values of NPQ increased rapidly after $15 \mathrm{~s}$ of light exposure and sustained a slight increasing trend thereafter at low irradiance in short and long-term for $A$. eugenea and $A$. hermannii and at high irradiance for the 

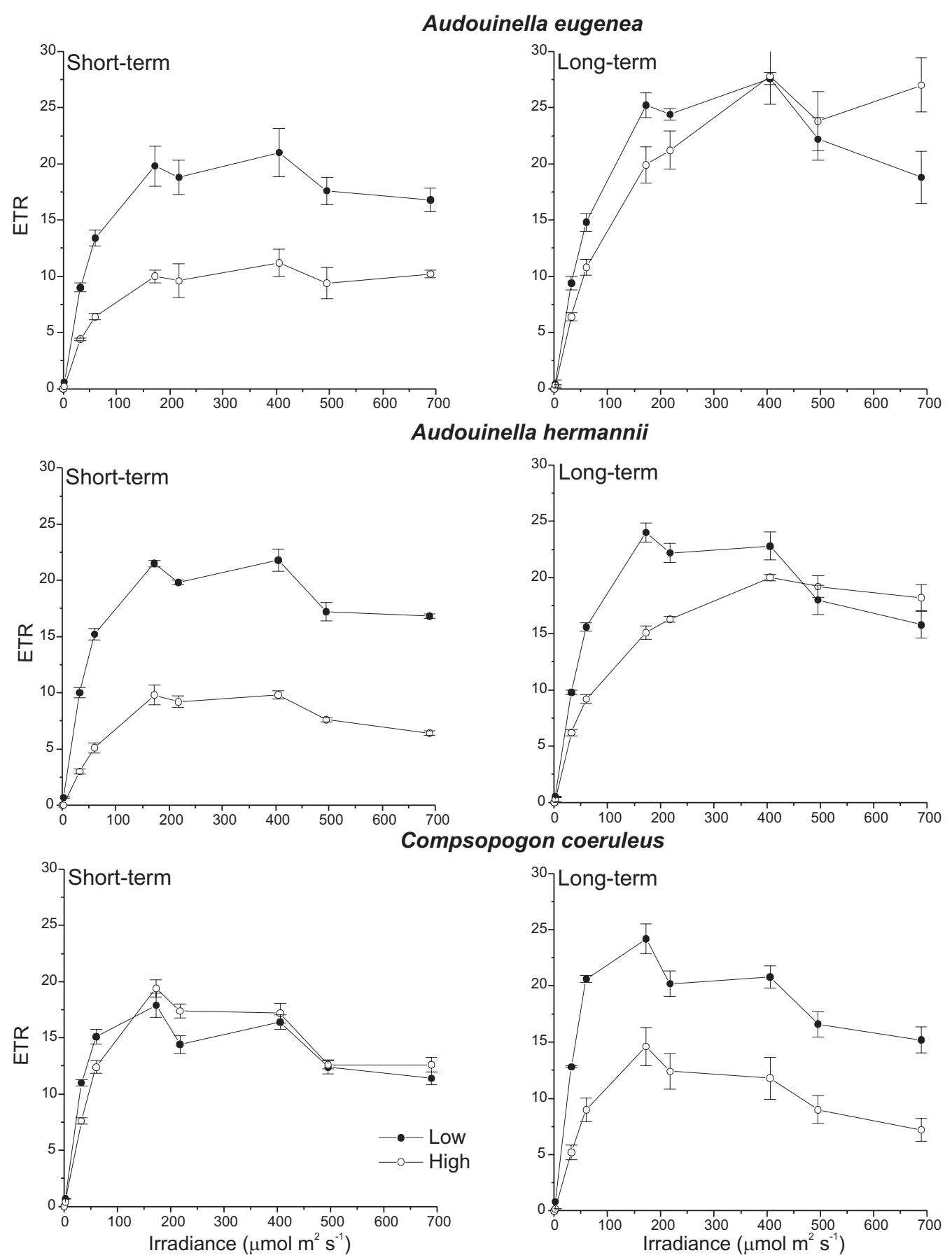

Figure 1. Photosynthesis-irradiance curves for the three red algal species tested under low $\left(65 \pm 5 \mu \mathrm{mol} \mathrm{m}^{-2} \mathrm{~s}^{-1}\right)$ and high $(300$ $\left.\pm 10 \mu \mathrm{mol} \mathrm{m} \mathrm{m}^{-2} \mathrm{~s}^{-1}\right)$ irradiances in short $(4 \mathrm{~d})$ and long-term $(28 \mathrm{~d})$. Bars indicate $\pm \operatorname{SD}(n=5)$. ETR = electron transport rate.

former species (Figure 3). Values of NPQ for A. hermannii at low irradiance in long-term showed a distinct trend, with a slight decrease after the initial peak and towards the end of the light period. The same trend was observed in long-term for this species at high irradiance. Values of
NPQ increased steadily during the light period for $C$. coeruleus in short-term at low irradiance, whereas they were null at high irradiance (Figure 3). In long-term NPQ increased rapidly up to 1:30 min and decreased slightly thereafter at low irradiance, whereas it decreased slightly 

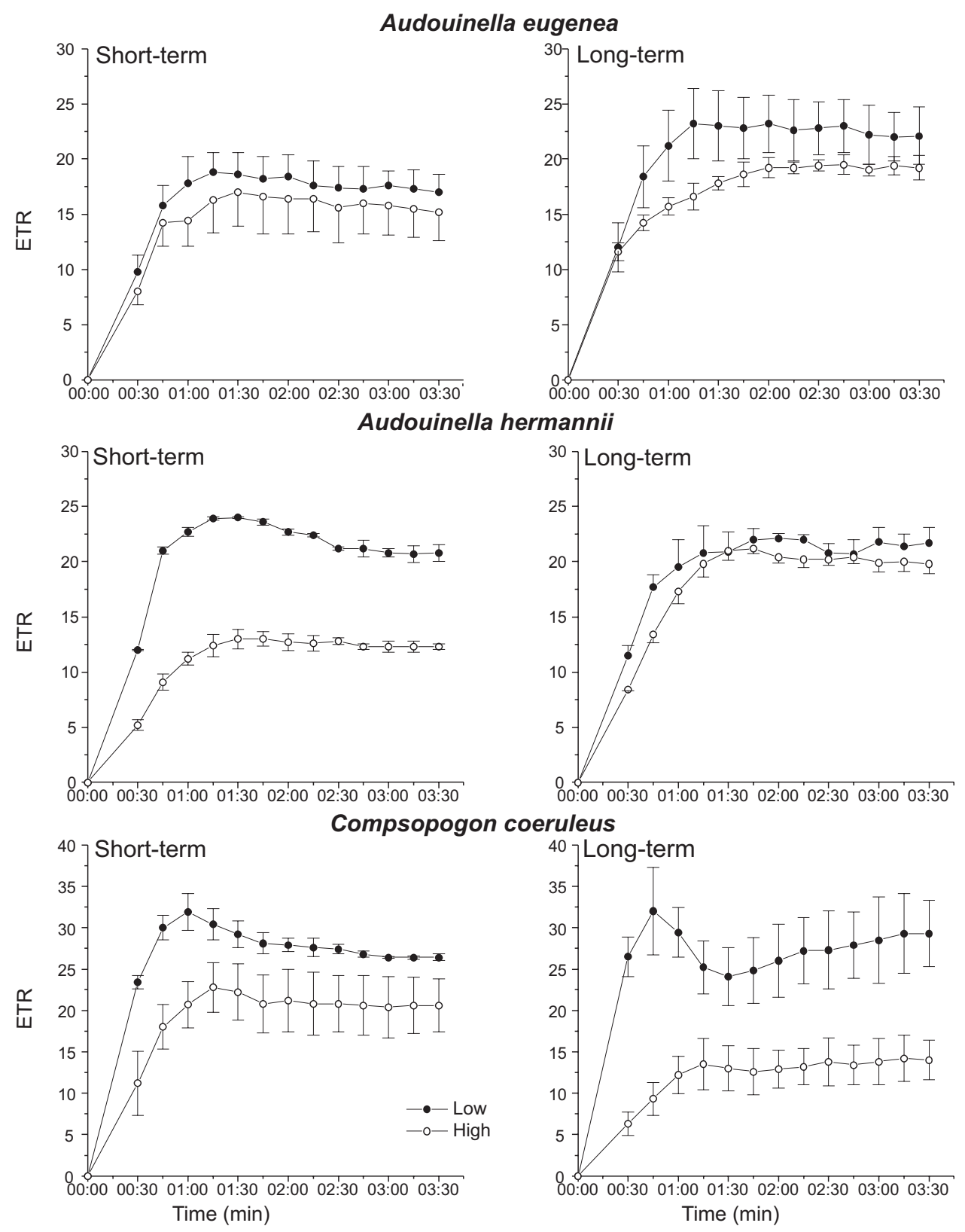

Figure 2. Dark/light (Kautsky) induction curves for electron transport rate (ETR) in dark-acclimated plants of the three red algal species tested under low $\left(65 \pm 5 \mu \mathrm{mol} \mathrm{m} \mathrm{s}^{-1}\right)$ and high $\left(300 \pm 10 \mu \mathrm{mol} \mathrm{m} \mathrm{m}^{-1}\right)$ irradiances in short (4 d) and long-term (28 d). Bars indicate $\pm \mathrm{SD}(n=5)$.

after the initial peak at high irradiance (Figure 3). Values of NPQ were significantly higher at low irradiance in all treatments $(t=6.7-9.3, P<0.001)$. Values of NPQ were positively correlated along the light period between low and high irradiance $(r=0.92-0.99, P<0.001)$ for $A$. eugenea and $A$. hermannii in short- and long-term, but not for C. coeruleus (Figure 3).

Potential quantum yield revealed similar patterns in short- and long-term, with consistently higher values under low irradiance for the three species (Figure 4). Values were significantly higher at low irradiance for $C$. coeruleus in short- and long-term $(t=2.6-5.1, P<0.05)$ and for $A$. hermannii in short-term $(t=2.8, P<0.01)$. Initial and final PQY values indicated a higher recovery capacity in short- than in long-term for A. eugenea (88-91 x 81-89\%) and $A$. hermannii (92-97 x 93-95\%), and more particularly for 


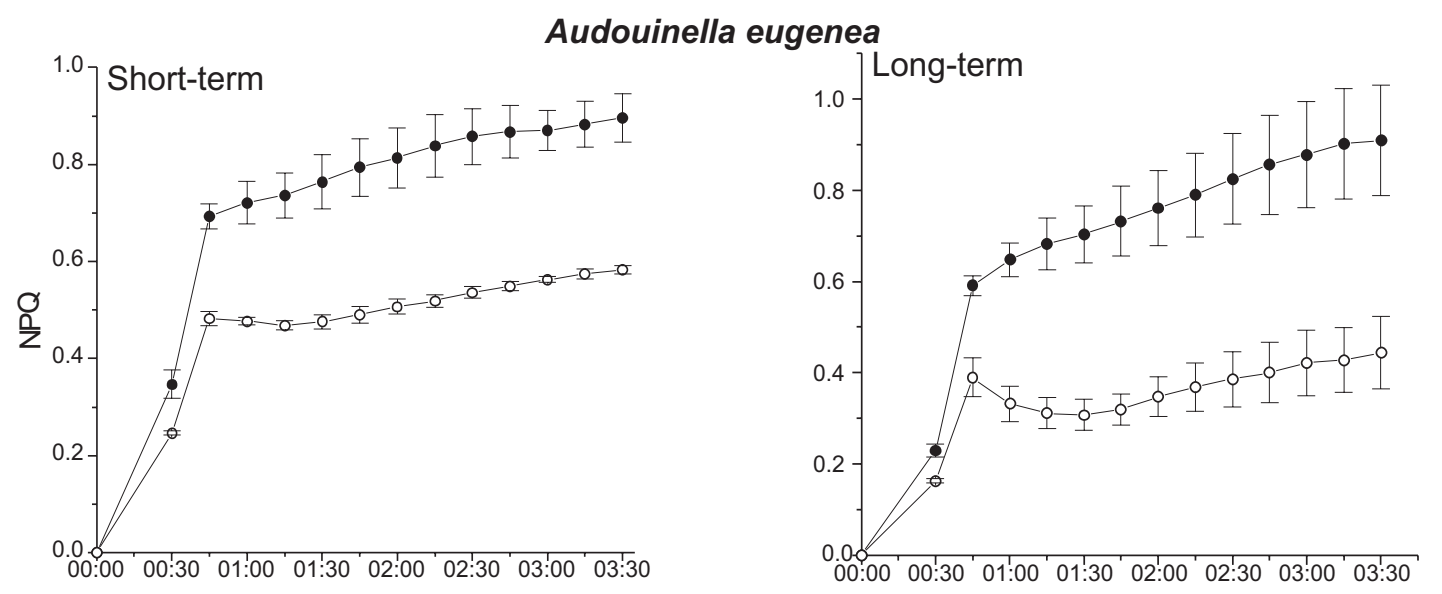

Audouinella hermannii
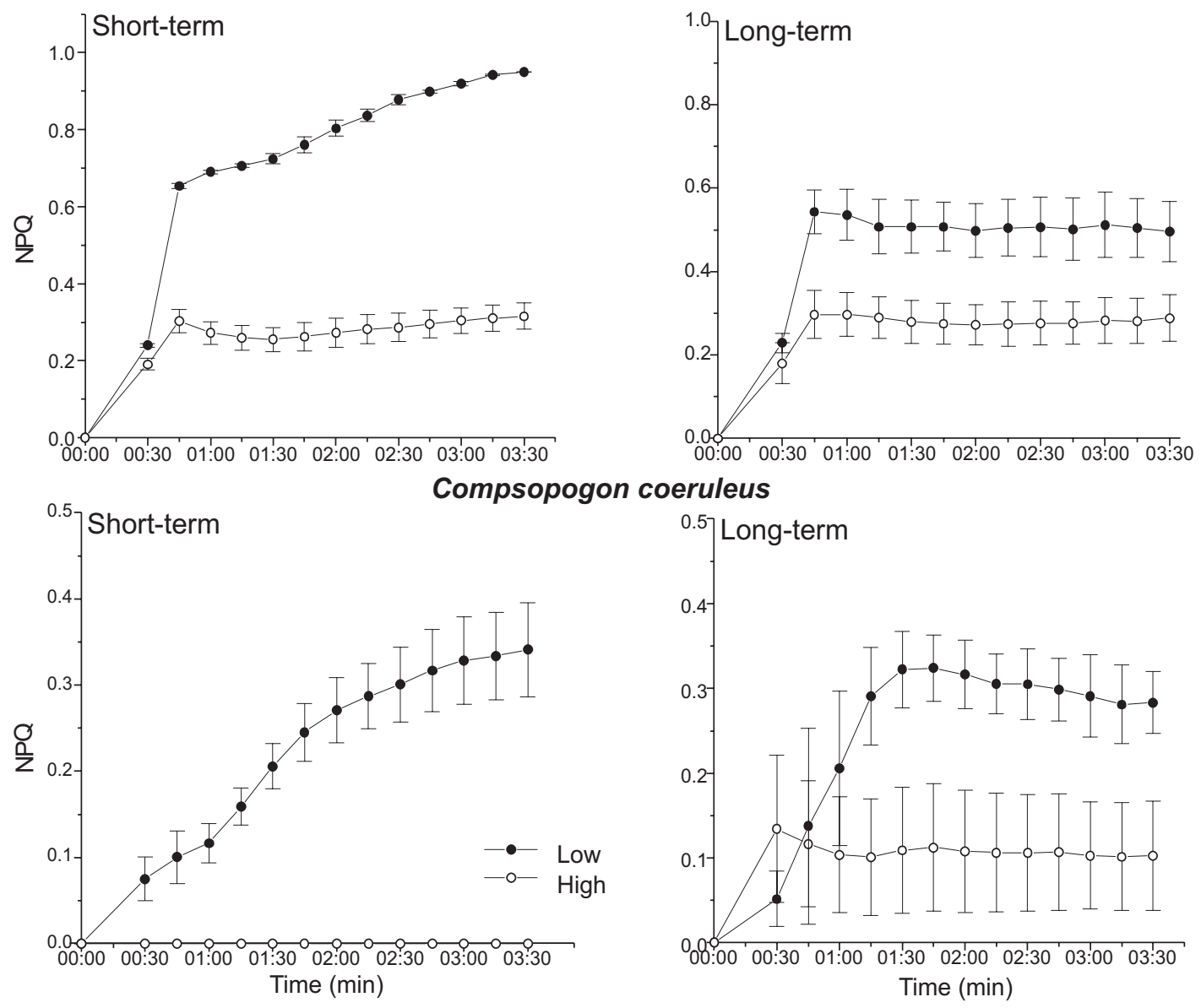

Figure 3. Dark/light (Kautsky) induction curves for nonphotochemical quenching coefficient (NPQ) in dark-acclimated plants of the three red algal species tested under low $\left(65 \pm 5 \mu \mathrm{mol} \mathrm{m}^{-2} \mathrm{~s}^{-1}\right)$ and high $\left(300 \pm 10 \mu \mathrm{mol} \mathrm{m}^{-2} \mathrm{~s}^{-1}\right)$ irradiances in short- $(4 \mathrm{~d})$ and long-term (28 d). Bars indicate $\pm \operatorname{SD}(n=5)$.

C. coeruleus (117-140 x 112-119\%). Values of PQY were positively correlated along the curve between low and high irradiance $(r=0.95-0.99, P<0.001)$ in short- and long-term for the three species.
Electron transport rate was positively correlated with NPQ in all treatments for A. eugenea $(r=0.92-0.96, P<$ $0.001)$ and $A$. hermannii $(r=0.86-0.94, P<0.001)$. On the other hand, positive correlation was observed for $C$. 
Audouinella eugenea
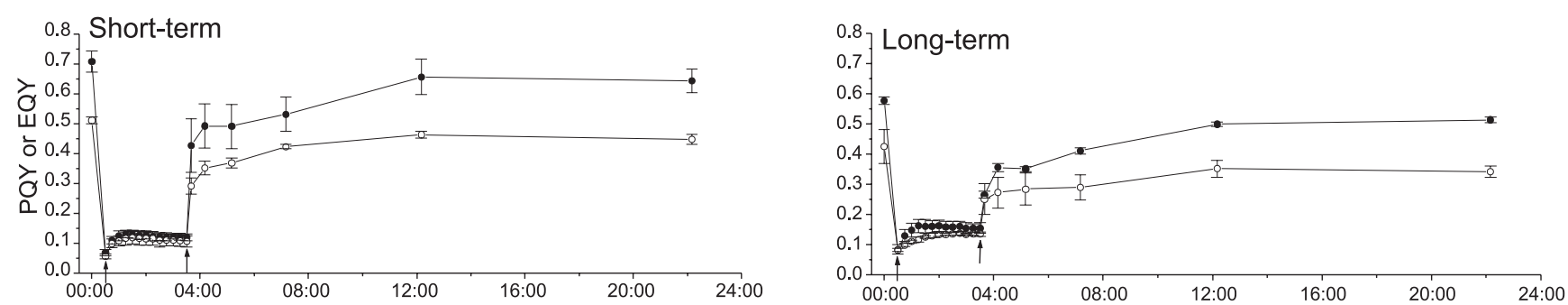

Audouinella hermannii
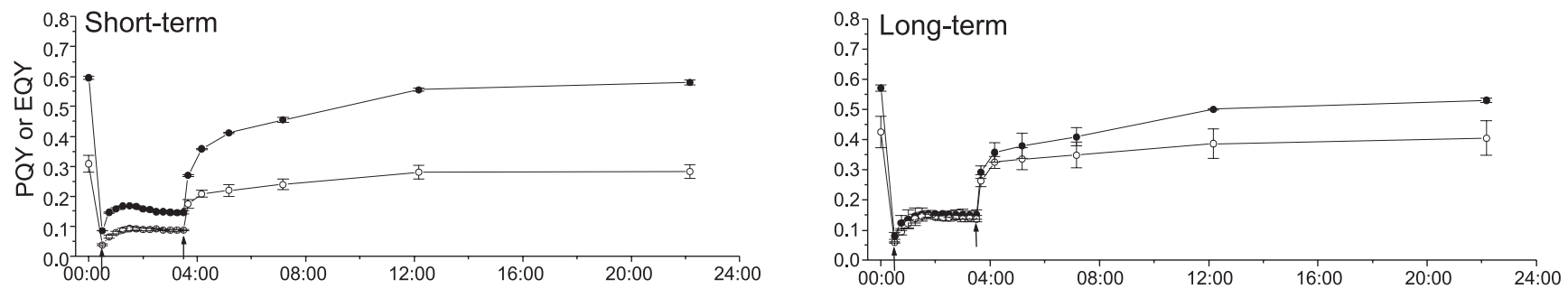

Compsopogon coeruleus
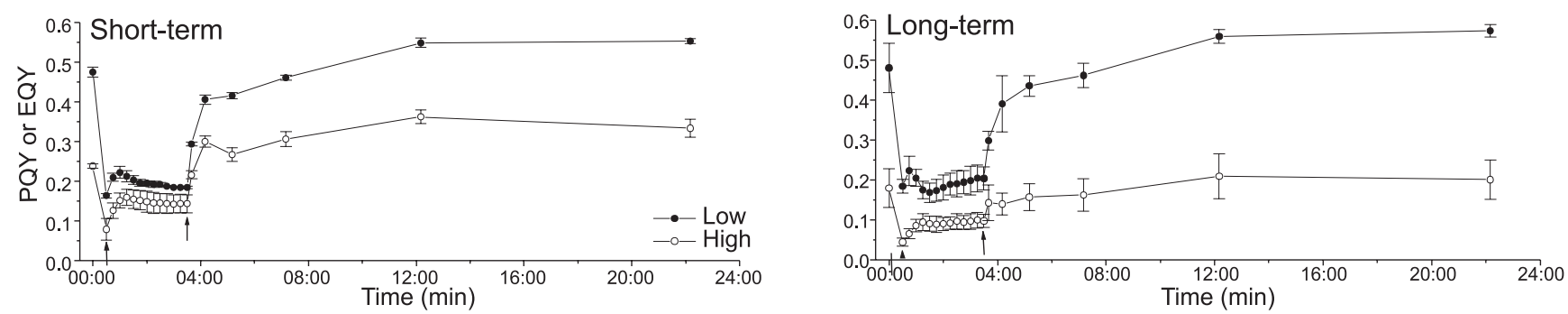

Figure 4. Dark/light (Kautsky) induction curves and recovery periods for quantum yield (potential quantum yield of PSII, PQY; and effective quantum yield of PSII, EQY) in dark-acclimated plants of the three red algal species tested under low (65 \pm $\left.5 \mu \mathrm{mol} \mathrm{m}^{-2} \mathrm{~s}^{-1}\right)$ and high $\left(300 \pm 10 \mu \mathrm{mol} \mathrm{m}^{-2} \mathrm{~s}^{-1}\right)$ irradiances in short- $(4 \mathrm{~d})$ and long-term $(28 \mathrm{~d})$. Bars indicate $\pm \mathrm{SD}(n=5)$. Arrows indicate the illumination period under constant irradiance $\left(170 \mu \mathrm{mol} \mathrm{m}^{-2} \mathrm{~s}^{-1}\right)$.

coeruleus $(r=0.55-0.66, P<0.05)$, but only in the longterm.

\section{DISCUSSION}

Curves of PI revealed distinct strategies of photoacclimation between Audouinella species and $C$. coeruleus. For A. hermannii and A. eugenea under longterm and $C$. coeruleus under short-term exposure to distinct irradiances, acclimation occurred by changing the PSU size, with fixed number of PSUs, as revealed by higher $\alpha$ and lower $I_{k}$ at low irradiance, as well as similar values of $\mathrm{P}_{\text {max }}$ in both irradiances (Ramus, 1981; Falkowski and La Roche, 1991). In this case, less light was required to saturate photosynthesis (lower $I_{k}$ ), i.e. PSUs were more efficient. On the other hand, the acclimation strategy for A. hermannii and A. eugenea under short- term and for $C$. coeruleus under long-term consisted of changing the PSU number and keeping the PSU size fixed, as revealed by lower values of $\alpha$ and $P_{\max }$ and higher $I_{k}$ under high irradiance (Ramus, 1981; Falkowski and La Roche, 1991). In this case, more light was needed to saturate photosynthesis (indicated by higher $\mathrm{I}_{\mathrm{k}}$ ). The strategy found in $C$. coeruleus was similar to that described for some macroalgae adapted to high irradiances, e.g. the charophyte Lamprothamnium papulosum (Küster et al., 2000), summer plants of a temperate population of the green alga Cladophora glomerata (Ensminger et al., 2000), and a tropical population of C. glomerata (Bautista and Necchi, 2008). This kind of photoacclimation can be considered as an efficient mechanism of photosynthesis control to cope with high irradiances.

Dynamic photoinhibition has been proposed as a 
reversible photoprotective mechanism against high irradiance (Osmond, 1994; Hanelt, 1996), consisting of a down-regulation of PSII to handle excess energy. This mechanism was shown to occur in freshwater red algae and is mostly related to the degree and extent of photoinhibition and recovery (Necchi, 2005). Generally, algae subjected to high irradiances have higher photoinhibition and recovery capacity than those inhabiting shaded sites, which tend to present chronic photoinhibition (Figueroa and Viñegla, 2001). We found higher values of the photoinhibition parameter at low irradiance for the three species, which is consistent with this point of view.

Sagert and Schubert (2000) showed that the light harvesting and the light-protecting pigments of the red alga Palmaria palmata are influenced by changes of the light amplitude, as well as light doses above the growth optimum. In contrast, acclimation of photosynthetic apparatus as a whole, as expressed by the $I_{k}$ values, is mainly determined by the mean light availability. Kaczmarczyk and Sheath (1991) demonstrated that the total irradiance controlled most pigment alterations in Batrachospermum boryanum and ratios of phycocyanin to phycoerythrin tended to decrease as irradiance increased. However, we found no clear trend for pigment contents, except for a consistent higher concentration of chlorophyll $a$ at low irradiance, which is generally reported in algae, and most particularly in green algae (Ensminger et al., 2000; Küster et al., 2000).

A light-induced decrease of EQY was observed in the three species analysed consisting of pronounced decreases from low to high irradiance. Ensminger et al. (2000) found similar results for $C$. glomerata, i.e., EQY decreased following increases in irradiance, but with higher decreases in low-light (shaded sites) than in highlight plants.

Dark/light induction curves revealed rapid increases in dissipation of excessive energy captured by reaction centers mainly at low irradiance, as reflected by higher values of NPQ. Ensminger et al. (2001) suggested that this mechanism is more likely to be found in low light plants of C. glomerata, i.e. from shaded sites than in those exposed to full sunlight. These findings support the statement that freshwater red algae are basically shaded-adapted plants. In addition, data from dark/light induction curves revealed higher recovery capacity of
PQY at low irradiance, as well as a higher recovery capacity under short than long-term for the three species. These data are consistent with those described by Ensminger et al. (2001), who found a decreasing recovery capacity of PQY with increasing exposure period to high irradiance by application of alternating sequences of high irradiances and subsequent recovery under dimlight conditions.

Garcia-Mendoza et al. (2002) showed that NPQ followed the kinetics of the light supply mode in the green alga Chlorella fusca, with the highest values found in high-light cultures. This pattern was proposed as an adequate photoprotective strategy of some green algae representing a possibility of fast responses to changes in irradiance. Values of NPQ derived from either PI and induction curves showed an opposite trend, with consistently higher values under low irradiances for the three species. This finding associated with the positive correlation of ETR with NPQ generally observed in the induction curves for the three species indicates another type of photosynthesis control. Thus, an increase in PSII energy conversion by electron transfer would be directly coupled to an increase in thermal dissipation of the excessive energy captured by reaction centers under prolonged exposure to high PAR. Thermal dissipation of energy presumably attenuates the negative effects of increasing levels of PAR to the photosynthetic apparatus. This mechanism has been observed in other macroalgal species (Necchi, 2005) and is perfectly applicable to explain the acclimation pattern observed in these three freshwater red algae.

Red algae have evolved a number of long- and shortterm strategies to survive under constantly fluctuating light field, involving changes from individual to molecular levels (Talarico and Maranzana, 2000). Accordingly, our results indicate that photoacclimation strategies to low and high irradiances differed between short- and long-term. Garcia-Mendoza et al. (2002) showed that photoacclimation of Chlorella fusca was dependent on both intensity and periodicity of the light supply. They found that long-term acclimation was a slower process comprising regulation of the amount of the various components of the photosynthetic apparatus. On the other hand, fast short-term regulation involves photoprotective processes, which are based on reversible changes in pools of existing molecules and 
variable assembly of supra-molecular complexes. Different acclimation processes occurred with respect to the reaction time needed until measurable effects could be distinguished, as well as the nature of these effects.

In summary, results confirmed that the three species are essentially shade-adapted algae but also revealed distinct photoacclimation strategies to deal with high irradiances. The two Audouinella species (A. eugenea and $A$. hermannii) had only characteristics of shadeadapted algae: 1) acclimation by changes of PSU size under long-term and by PSU number under short-term; 2) higher values of $\beta$ and NPQ, and lower values of EQY at low irradiance; 3 ) higher recovery capacity of PQY at low irradiance and under short-term; 4) highly significant positive correlation of ETR with NPQ. In addition, $C$. coeruleus mixed some characteristics of sun-adapted algae: 1) acclimation by changes of PSU number under long-term and by PSU size under short-term; 2) higher recovery capacity of EQY than the other two species; 3 ) weak or no correlation of ETR with NPQ. Thus, these characteristics indicate that $C$. coeruleus cope with high irradiances more efficiently than the Audouinella species.

Acknowledgements: This research was supported by a CNPq scholarship awarded to AINB (520551/96-6) and a research grant (304067/2003-2) to ON; laboratory assistance by Maria Helena Carabolante, UNESP and English review by Solange Aranha, UNESP, Language Department, are greatly appreciated.

\section{REFERENCES}

Bautista AIN, Necchi O Jr. (2008) Photoacclimation in a tropical population of Cladophora glomerata (Chlorophyta) from southeastern Brazil. Braz. J. Biol. 67: in press.

Beer S, Eshel A (1985) Determining phycoerythrin and phycocyanin concentrations in aqueous crude extracts of red algae. Austr. J. Mar. Freshwater Res. 36:785-792.

Conde-Álvarez RM, Pérez-Rodríguez E, Altamirano M, Nieto JM, Abdala R, Figueroa FL, Flores-Moya A (2002) Photosynthetic performance and pigment content in the aquatic liverwort Riella helicophylla under natural solar irradiance and solar irradiance without ultraviolet light. Aquat. Bot. 73:47-61.
Ensminger I, Xyländer M, Hagen C, Braune W (2000) Strategies providing success in a variable habitat: II. Ecophysiology of photosynthesis of Cladophora glomerata. Plant Cell Environ. 23:1129-1136.

Ensminger I, Xyländer M, Hagen C, Braune W (2001) Strategies providing success in a variable habitat: III. Dynamic control of photosynthesis in Cladophora glomerata. Plant Cell Environ. 24:769-779.

Falkowski PG, Dubinsky Z, Wyman J (1985) Growthirradiance relationships in marine phytoplankton. Limnol. Oceanogr. 30:311-321.

Falkowski PG, LaRoche J (1991) Acclimation to spectral irradiance in algae. J. Phycol. 27:8-14.

Falkowski PG, Raven JA (1997) Aquatic photosynthesis. Blackwell Science, Malden.

Figueroa FL, Viñegla B (2001) Effects of solar UV radiation on photosynthesis and enzyme activities (carbonic anhydrase and nitrate reductase) in marine macroalgae from southern Spain. Rev. Chil. Hist. Nat. 74:237-249.

Gallagher JC, Wood AM, Alberte RS (1984) Ecotypic differentiation in the marine diatom Skeletonema costatum: influence of light intensity on the photosynthetic apparatus. Mar. Biol. (Berl.) 82:121-134.

Garcia-Mendoza E, Matthijs HCP, Schubert H, Mur LR (2002) Non photochemical quenching of chlorophyll fluorescence in Chorella fusca acclimated to constant and dynamic light conditions. Photosynth. Res. 74:303-315.

Hanelt D (1996) Photoinhibition of photosynthesis in marine macroalgae. In Figueroa FL, Jiménez JL, PerezLlorens, Niell FX (eds), Underwater Light and Algal Photobiology, pp.243-248. CSIC, Barcelona.

Kaczmarczyk D, Sheath RG (1991) The effect of light regime on the photosynthetic apparatus of the freshwater red alga Batrachospermum boryanum. Cryptogam. Algol. 12:249-263.

Kain JM (1987) Seasonal growth and photoinhibition in Plocamium cartilagineum (Rhodophyta) off the Isle of Man. Phycologia 26:88-99.

Kirk JTO (1994) Light and photosynthesis in aquatic ecosystems, $2^{\text {nd }}$ edition. Cambridge University Press, Cambridge.

Küster A, Schaible R, Schubert H (2000) Light acclimation of the charophyte Lamprothamnium papulosum. Aquat. Bot. 68:205-216. 
Necchi O Jr (2005) Light-related photosynthetic characteristics of freshwater rhodophytes. Aquat. Bot. 82:193-209.

Necchi O Jr, Zucchi MR (2001) Photosynthetic performance of freshwater Rhodophyta in response to temperature, irradiance, $\mathrm{pH}$ and diurnal rhythm. Phycol. Res. 49:305-318.

Osmond CB (1994) What is photoinhibition? Some insights from comparisons of shade and sun plants. In Baker NR, Bowyer JR (eds), Photoinhibition of Photosynthesis: from Molecular Mechanisms to the Field, pp.1-24. Bios Scientific Publishers, Oxford.

Perry M, Talbot M, Alberte R (1981) Photoadaptation in marine phytoplankton: response of the photosynthetic unit. Mar. Biol. (Berl.) 62:91-101.

Platt T, Gallegos CL, Harrison WG (1980) Photoinhibition of photosynthesis in natural assemblages of marine phytoplankton. J. Mar. Res. 38:687-701.

Ramus J (1981) The capture and transduction of light energy. In Lobban CS, Wynne MJ (eds), The Biology of Seaweeds, pp.458-492. Blackwell Science, Oxford.

Ritz M, Thomas JC, Spilar A, Etienne AL (2000) Kinetics of photoacclimation in response to a shift to high light of the red alga Rhodella violacea adapted to low irradiance. Plant Physiol. 123:1415-1425.

Sagert S, Schubert H (2000) Acclimation of Palmaria palmata (Rhodophyta) to light intensity: comparison between artificil and natural fields. J. Phycol. 36:11191128.

Schreiber U, Bilger W, Neubauer C (1994) Chlorophyll fluorescence as a non-intrusive indicator for rapid assessment of in vivo photosynthesis. In: Schulze ED, Caldwell MM (eds), Ecophysiology of Photosynthesis, pp.49-70. Springer-Verlag, Berlin.

Sheath RG (1984) The biology of freshwater red algae. In: Round FE, Chapman DJ (eds), Progress in Phycological Research, pp.89-157. Biopress, Bristol.

Talarico L, Maranzana G (2000) Light and adaptive responses in red macroalgae: an overview. J. Photochem. Photobiol. B 56:1-11.

van Kooten O, Snel JFH (1990) The use of chlorophyll fluorescence nomenclature in plant stress physiology. Photosynth. Res. 25:147-150.

Wetzel RG, Likens GE (2000) Limnological analyses, $3^{\text {rd }}$ ed. Springer, New York.

White AJ, Critchley C (1999) Rapid light curves: a new fluorescence method to assess the state of the photosynthetic apparatus. Photosynth. Res. 59:63-72.

Zar JH (1999) Biostatistical Analysis. $4^{\text {th }}$ ed. Prentice Hall, New Jersey.

Zucchi MR, Necchi OJr (2001) Effects of temperature, irradiance and photoperiod on growth and pigment content in some freshwater red algae in culture. Phycol. Res. 49:103-114. 